\begin{tabular}{l|c|c}
\hline ISSN: 0001-5113 & ACTA ADRIAT., & ORIGINAL SCIENTIFIC PAPER \\
AADRAY & $62(2): 127-138,2021$ & \\
\hline
\end{tabular}

\title{
Daily and seasonal population dynamics of Brachynotus sexdentatus (Risso, 1827) (Varunidae: Brachyura: Decapoda) in a temperate coastal lake
}

\author{
Salvatore GIACOBBE ${ }^{1 *}$, Paolo De PASQUALE ${ }^{2}$ and Erika M.D. PORPORATO ${ }^{3}$ \\ ${ }^{1}$ Dept. of Chemical, Biological, Pharmaceutical and Environmental Sciences, Messina \\ University, Viale Ferdinando Stagno d'Alcontres 31, 98166 Messina, Italy
}

${ }^{2}$ Dept. of Biomedical and Dental Sciences and Morphofunctional Imaging, Messina University, Via Consolare Valeria 1, 98125 Messina, Italy

${ }^{3}$ IMC - International Marine Centre, Loc. Sa Mardini, 09170, Oristano, Italy

"Corresponding author, e-mail: sgiacobbe@unime.it

The grapsoid Brachynotus sexdentatus (Risso, 1827) is a small sized Mediterranean crab, whose ecology is poorly known despite frequently cited in the scientific literature. High densities occasionally recorded in estuarine habitats suggest this opportunistic species might play a functional role in connecting benthic primary production with consumption at higher trophic levels. The brackish Lake Ganzirri (north-eastern Sicily) hosts a population of this varunid crab, whose differential distribution of juveniles and adults, respectively found on hard and soft substrates, involves different habitat preferences and consequent resource partitioning. Investigation on daily and seasonal dynamics of the soft-bottom dwelling adults showed a male biased population, with size-related differences between sex, station, season and female reproductive phase. Our data, suggesting an annual life span, prolonged spawning and related continuous recruitment, are in agreement with the intrinsic unpredictability of the colonized brackish environment. At last, preliminary in aquaria observations on the characteristic male cheliped vesicles, showed they might involved in agonistic and courtship behaviour.

Key words: Littoral Brachyura; sex ratio; brackish lagoons; protected environments dynamics; Mediterranean 


\section{INTRODUCTION}

Crabs (Decapoda: Brachyura), are most prominent members of the estuarine macrobenthic communities, notably influencing material cycling and energy flow (CHU et al., 2013, and references therein). The population dynamics of Mediterranean species, nevertheless, are poorly known, except for the popular and edible Carcinus aestuarii Nardo, 1847 (CILENTI et al., 2014).

The genus Brachynotus de Haan, 1833 includes six species (www.marinespecies.org) whose habitat is restricted to intertidal and upper subtidal zones. Five species have been reported for the Mediterranean, including the problematic B. marmoratus (Olivi, 1792), a taxon totally neglected by recent literature. Molecular investigations (SCHUBART et al., 2001) indicated B. atlanticus Forest, 1957 and B. foresti Zariquiey Álvarez, 1968 as morphologically well distinguishable sister species. Conversely, a clear genetic separation was not found for the close $B$. gemmellari (Rizza, 1839) and B. sexdentatus (Risso, 1827) (SCHUBART et al., 2001), recognized as different species after FROGLIA \& MANNING (1978), but only distinguiscible by some subtle characters of adults and larval stages (PESSANI $e t$ al., 1998, 2004). In this regard, the possibility that the subtidal $B$. gemmellari and the intertidal to shallow subtidal $B$. sexdentatus may represent different ecophenotypes of a single species has been suggested (SCHUBART et al., 2001). In this paper, regardless of the taxonomic implications, we deem appropriate to keep separate $B$. sexdentatus from $B$. gemmellari, due to differences in their functional traits, being the former an epifaunal grazer whilst the latter is a burrower and scavenger (ATKINSON et al., 1998).

In Mediterranean Sea and close Gulf of Cadiz, the occurrence of $B$. sexdentatus is largely under-evaluated, with numerous but scattered and almost incidental reports both in coastal and transitional waters, e.g. in Israel (LEWINSOHN \& HOLTHUIS, 1964), Adriatic (MANNING \& ŠTEVČIĆ, 1982), North-West Mediterranean (ABELLÓ et al., 1988), Aegean (BALKIS et al., 2001), Gulf of Taranto (STABILI et al., 2013), Tunisian (OUNIFI-BEN AMOR et al., 2017), and even in inland brackish basins (KHALIL et al., 2017). Reports outside their normal distributionary range include Swansea, U.K. (NAYLOR, 1957) and the French Atlantic coast (D'UDEKEM D'ACOZ, 1999), although in this latter any evidences of established breeding populations is lacking. The effective status of $B$. sexdentatus as a critically endangered species in the Black Sea, after RODRÍGUEZ \& SUÁREZ (2001), has been confirmed by MICU (2007). Later, ZELOTA et al. (2016) reported the dramatic decline of $B$. sexdentatus in the Sea of Azov, as a possible effect of the non-indigenous Rhithropanopeus harrisii (Gould, 1841) spread. Moreover, recent investigation on the effects of ocean acidification on decapods communities associated to Posidonia oceanica beds (ZUPO \& VIEL, 2021), indicated B. sexdentatus as not directly menaced, whilst long term monitoring of benthic communities in the Lake Qarun, inland Egypt, testified changes in B. sexdentatus population density, with remarkable peaks after increased eutrophication (SHADRIN et al., 2016). At last, data about population dynamics are lacking, despite some evidence of a significant functional role of $B$. sexdentatus, as prey of both widespread (VELASCO et al., 2010; COMPAIRE et al., 2016 and 2018; AYDIN \& BENGIL, 2020; AYDIN \& MAZLUM, 2020) and endemic fishes (BENGIL \& AYDIN, 2020).

In this paper, the occurrence of a large population of $B$. sexdentatus in a Mediterranean coastal lake is reported, and data on population structure, seasonal changes, daily cycles and small-scale distribution are provided. The aim of the study is to provide first basic information about a neglected species which might play a key role in estuarine habitats.

\section{MATERIAL AND METHODS}

\section{Study area}

The investigated site, Lake Ganzirri $\left(38^{\circ} 15^{\prime} 38^{\prime \prime} \mathrm{N}\right.$; $\left.15^{\circ} 37^{\prime} 2^{\prime \prime} \mathrm{E}\right)$, together with the differently featured Lake Faro (LEONARDI et al., 2009), belongs to the Capo Peloro Lagoon, a protected transitional environment, located in the Strait of Messina, central Mediterranean (Fig. 1A, B). The lake, a microtidal coastal lagoon 


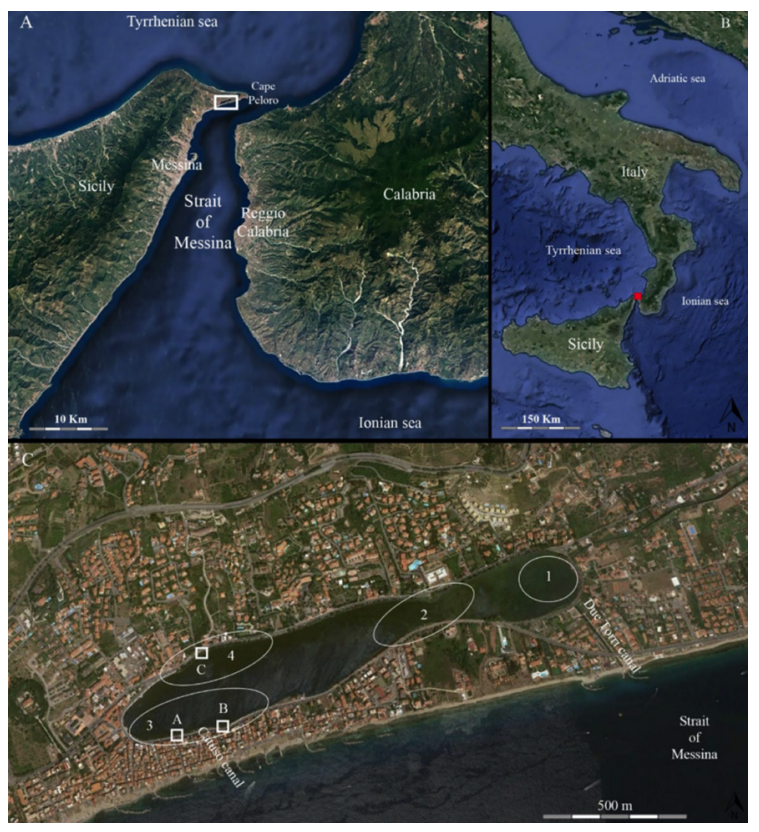

Fig. 1. Sampling site, in respect to the central Mediterranean (A), the Strait of Messina (B), and the Lake Ganzirri (C). Numbers from 1 to 4 indicate the preliminary investigated areas; letters $A, B$ and $C$ indicate the present sampling stations.

covering a 34 ha area and reaching $7 \mathrm{~m}$ maximum depth, is connected to the sea by the "Due Torri" canal, in the eastern limit, while in the westernmost area a subterranean minor canal, "Catuso", allows sporadic water exchanges (Fig. 1C). Such connections, together with the elongated basin outline and different bathymetric shape, determine a hydrological differentiation between a smaller and shallower zone, directly connected to the sea, and a wider and deeper zone, characterized by a slow water recirculation (FERRARIN et al., 2013). Such reduced circulation is responsible of seasonal blooms of floating macroalgae and occasional dystrophic crisis which, however, are more pronounced in the most dynamic eastern zone than in the most confined western zone. According to the "Provincia Regionale di Messina", official management body of the reserve (https://www.cittametropolitana.me.it/servizi/informazioni-ambientali/ tutela-della-acque/monitoraggio-corpi-idrici/), lower values of dissolved oxygen have been recorded in August $\left(1 \mathrm{mg} \mathrm{L}^{-1}\right)$ and July (4 mg $\left.\mathrm{L}^{-1}\right)$, respectively. The same source reported annual temperature ranging from 14.8 to 27.5
${ }^{\circ} \mathrm{C}$ in both zones, coupled with a wider salinity range in the west (25.6-36.2 psu) with respect to the east $(31.3-32.2 \mathrm{psu})$. The lake bottom experiences notable sediment reworking, due to the traditionally practiced clam and cockle culture. The lake benthic fauna is poorly known, due to a sparse and dated literature, so that only four species of decapods are known, including B. sexdentatus (BOTTARI et al. 2005).

\section{Sampling and determinations}

Brackish-water benthic communities have been investigated in the framework of the PRA 2008/2009 program: "Settlement dynamics and colonization of allochthonous assemblages in the Capo Peloro Lagoon". A visual census of macrobenthic fauna (GIACOBBE, unpublished data), was carried out in four sites representative of the whole Lake Ganzirri (Fig. 1C), monthly from April 2008 to April 2009, and seasonally until June 2011. In each site, a $100 \mathrm{~m}^{2}$ surface station was examined by means of a $5 \times 5 \mathrm{~m}$ grid (four random replicates), similarly to the one described in GIACOBBE \& DE MATTEO (2013) for the nearby Lake Faro. In such a context the frequency of decapod crustaceans was estimated, distinguishing between adult and juvenile specimens.

Based on such preliminary observations, quantitative samplings were carried out inside the two westermost sites, due to the highest adult density therein recorded. Three soft bottom stations were individuated, two of which near the Catuso Canal (site 3: stations A and B), and one into the opposite lake bank (site 4: station C) (Fig. 1C). Each sampling area was defined by a $20 \mathrm{~m}^{2}$ removable grid, positioned upon each fixed station, 0.5 - 1 meter depth. All specimens inside the sampling area were collected by means of a $2 \mathrm{~mm}$ mesh triangular hand net. The stations were monitored seasonally, in July and October 2011, and in January and April 2012, repeating the sampling at three time of the day namely sunrise, midday and sunset, for a total of 36 samples.

Carapace width (CW) and length (CL) of each $B$. sexdentatus specimen were measured by 
means of a Vernier calliper ( $\pm 0.1 \mathrm{~mm})$, before returning the specimen to the sampling site. The presence or absence of the characteristic vesicle in male cheliped was recorded. The stage of ovarian maturation of the females was evaluated in the field, by lens, according to the following empiric scale, simplified from CHU (1999): stage 0 , no visibly developed ovaries; stage I, colourless; stage II, white to ivory; III, yellow to dark orange (well recognizable embryos).

Lastly, some prelimary observations on male competition have been carried out in aquaria on 20 specimens, 5 of which lacking the cheliped vesicle. A total of 40 couples of randomly selected specimens were considered, and any competitive behaviors occurring within 15 ' was recorded.

\section{Statistical analysis}

The population structure was analysed considering size class frequencies, sex, site, season and time of the day. Tide phase was not considered, being it patently irrelevant in such a microtidal environment. Prior to analysis, exploratory and normality tests were carried out (ZUUR et al. 2010). The relationship between CW and $\mathrm{CL}$ was evaluated by fitting a linear regression model, and the sex interaction effect was tested. Afterwards, separately for males and females was evaluated the correlation between $\mathrm{CW}$, the dependent variable, and sampling station, season and time of the day as explanatory variables.

The statistical analyses were carried out using the software program R. version 4.0.5 (R Development Core Team, 2021).

\section{RESULTS}

According to the preliminary survey carried out in the Lake Ganzirri between spring 2008 and spring 2011, the grapsoid Brachynotus sexdentatus was by far the most abundant subtidal brachyuran crabs, resulting in more than two thousand specimens counted vs. 12 specimens of Carcinus aestuarii Nardo, 1847 and only 5 Eriphia verrucosa (Forskal, 1775).

Adults occurred sporadically in soft bottoms of the eastern areas (estimated average density of individuals $/ \mathrm{m}^{2}$ and standard deviation: $0.08 \pm 0.09$ ind. $/ \mathrm{m}^{2}$ in st. $1 ; 0.03 \pm 0.03$ ind./ $\mathrm{m}^{2}$ in st.2), rapidly increasing their frequency westwards $\left(1.15 \pm 0.30\right.$ ind. $/ \mathrm{m}^{2}$ in st. $3 ; 1.45 \pm 0.92$ ind. $/ \mathrm{m}^{2}$ in st.4), mostly associated to the green algae Ulva sp. and Enteromorpha sp. Juveniles, in contrast, massively settled in the eastern areas $\left(1.15 \pm 0.57\right.$ ind. $/ \mathrm{m}^{2}$ in st. $1 ; 1.09 \pm 0.62$ ind. $/ \mathrm{m}^{2}$ in st.2), notably decreasing westwards $(0.21 \pm 0.30$ ind. $/ \mathrm{m}^{2}$ in st. $3 ; 0.01 \pm 0.83$ ind. $/ \mathrm{m}^{2}$ in st.4) (Fig. 2), exclusively colonizing outcropping hard substrates, as pilings and concrete boulders.

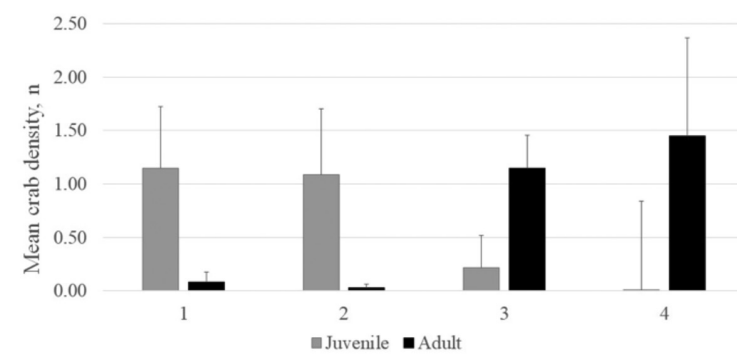

Fig. 2. Average distribution of adults and juveniles $B$. sexdentatus in the Lake Ganzirri according to the preliminarily monitoring (four sites examined).

The seasonal survey from autumn 2011 to summer 2012 resulted in 1445 individuals counted, with the highest numbers in autumn (563 individuals), followed by summer, spring and winter (509, 293 and 75 individuals, respectively). The evaluated densities were $3.1 \pm 1.6$; $2.8 \pm 1.5 ; 1.6 \pm 1.0$ and $0.6 \pm 0.5$ individuals $/ \mathrm{m}^{2}$ respectively. Density showed some differences between stations, with a maximum in $\mathrm{B}$ (2.7 \pm 1.6$)$, followed by $C(2.0 \pm 1.8)$, and minimum in $\mathrm{A}(1.42 \pm 1.1)$.

Mean density of males and females in each station indicated a differential distribution according to the seasons (Fig. 3), with the highest concentration near the "Catuso" canal (St. B) in spring-summer.

The global M:F sex ratio was 2.07, significantly in favour of males (967 males vs. 478 females), with the strongest differences in summer and autumn and lesser in winter and spring (Table 1). Carapace width (CW) in males ranged from 0.50 to $2.20 \mathrm{~cm}$, slightly greater than in females (maximum size $2.05 \mathrm{~cm}$ ). Slight differences in modal distribution of respective 


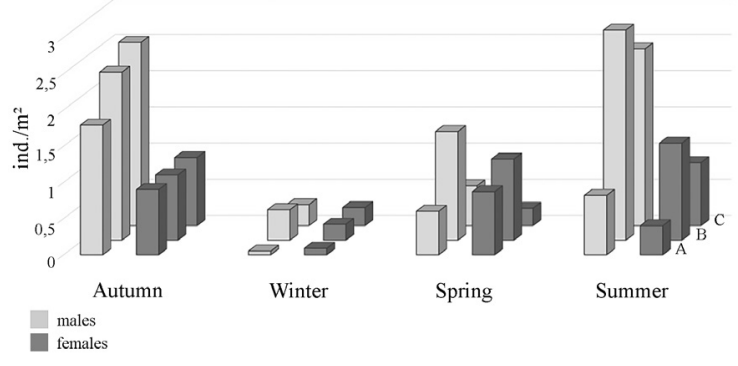

Fig. 3. Mean density of males and females B. sexdentatus, according to the stations and seasons. vs. $1.20 \mathrm{~cm}$ and $1.50 \mathrm{~cm}$ in females) which might reflect the Autumn juvenile recruitment. Males and females showed the same CW/CL ratio and growth pattern (Fig. 5), fitting with a linear regression $\left(\mathrm{R}^{2}: 0.9621\right)$. Overall, 39\% of females were ovigerous, but this proportion was higher in summer $(59.72 \%)$ and autumn $(52.15 \%)$. No ovigerous females were observed in winter, but a faint recovery occurred in spring $(8.27 \%)$. Moreover, increasing rate of gonad

Table 1. Chi-square test results applied to seasonal sex ratios.

\begin{tabular}{|l|l|l|l|l|l|l|l|l|l|}
\hline & $\begin{array}{l}\mathbf{n} \\
\text { males }\end{array}$ & $\begin{array}{l}\mathbf{n} \\
\text { females }\end{array}$ & $\mathbf{n}$ Total & $\begin{array}{l}\text { \% } \\
\text { males }\end{array}$ & \% females & $\begin{array}{l}\text { Number of } \\
\text { males/ females } \\
\text { expected }\end{array}$ & $\chi^{\mathbf{2}}$ & $\begin{array}{l}\chi^{2} \\
\text { critic }\end{array}$ & $\mathbf{P}$ \\
\hline Spring & 160 & 133 & 293 & 54.61 & 45.39 & 146.5 & 0.02 & 0.45 & 0.11 \\
\hline Summer & 363 & 147 & 510 & 71.18 & 28.82 & 255 & 0.00 & 0.45 & $\mathbf{0 . 0 0}$ \\
\hline Autumn & 399 & 164 & 563 & 70.87 & 29.13 & 281.5 & 0.00 & 0.45 & $\mathbf{0 . 0 0}$ \\
\hline Winter & 45 & 34 & 79 & 56.96 & 43.04 & 39.5 & 0.08 & 0.45 & 0.22 \\
\hline
\end{tabular}
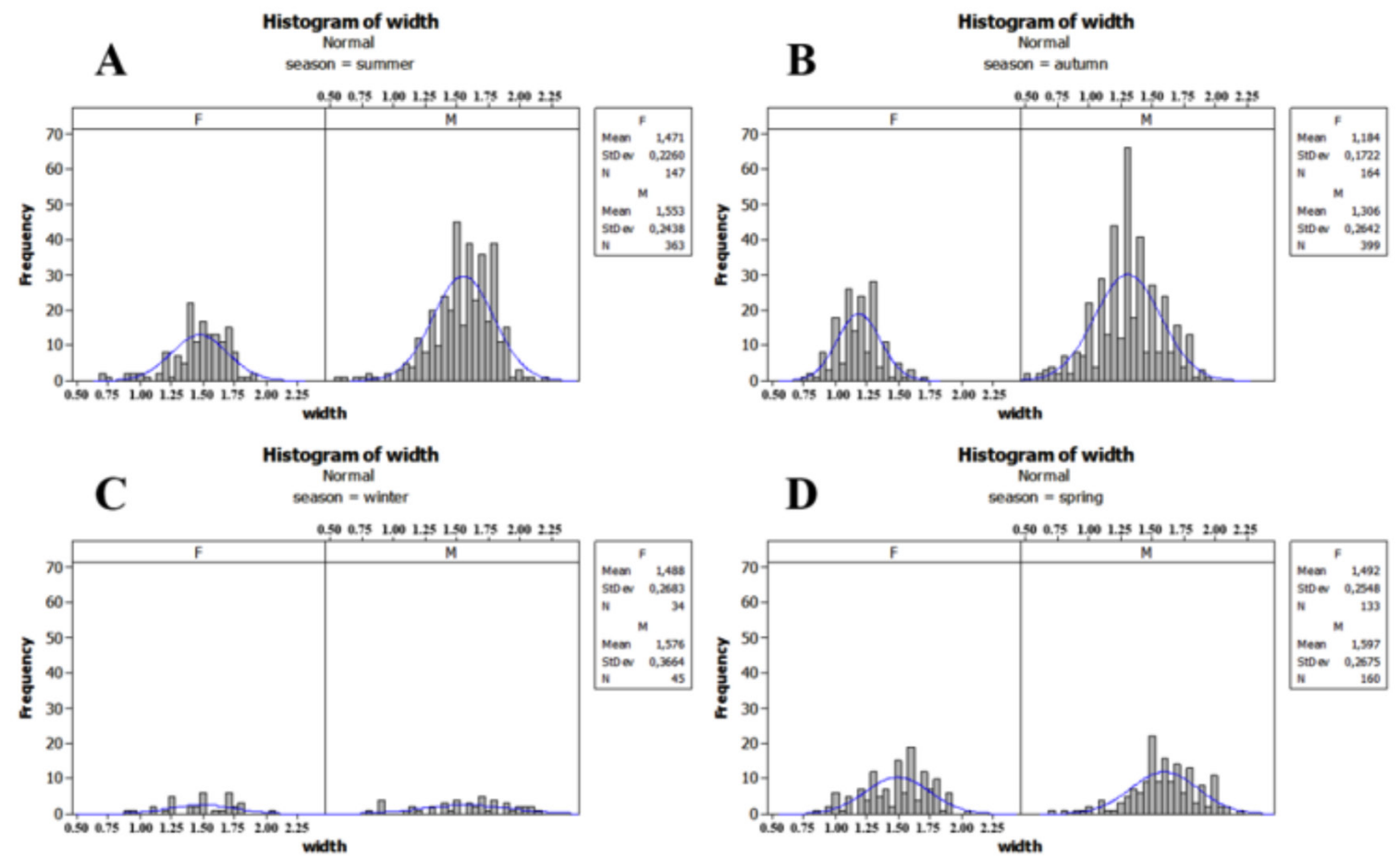

Fig. 4. Carapace width frequency distribution of male $(M)$ and female $(F)$ specimens for each season: summer (A), autumn (B), winter (C) and spring (D).

size classes confirmed that males were generally largest (Fig. 4; Tab. 2).

The size frequency distribution showed a mode shift according to the season (from 1.30 $\mathrm{cm}$ in autumn to $1.60 \mathrm{~cm}$ in spring in males, maturity from summer to autumn was evident (Fig. 6). The minimum reproductive female size was $6 \mathrm{~mm}$.

All males larger than $9 \mathrm{~mm}(91 \%$ of whole male population), in each season showed the 
Tab. 2. Frequency distribution of the female reproductive status, and frequency of male with and without spermatic vesicle: $N$, number of organisms; $C W$, Carapace Width; CL, Carapace Length; S.D., Standard Deviation.

\begin{tabular}{|l|l|l|l|l|l|}
\hline & N & $\begin{array}{l}\text { CW } \\
\text { mean }\end{array}$ & S.D. & $\begin{array}{l}\text { CL } \\
\text { mean }\end{array}$ & S.D. \\
\hline $\begin{array}{l}\text { females } \\
\text { Not brooding }\end{array}$ & 292 & 1.39 & 0.27 & 1.11 & 0.22 \\
\hline early embryos & 53 & 1.49 & 0.21 & 1.19 & 0.17 \\
\hline embryos & 72 & 1.35 & 0.24 & 1.09 & 0.20 \\
\hline late embryos & 61 & 1.29 & 0.24 & 1.04 & 0.20 \\
\hline $\begin{array}{l}\text { males } \\
\text { No vesicle }\end{array}$ & 88 & 1.40 & 0.37 & 1.12 & 0.30 \\
\hline sperm vesicle & 879 & 1.46 & 0.28 & 1.18 & 0.23 \\
\hline
\end{tabular}

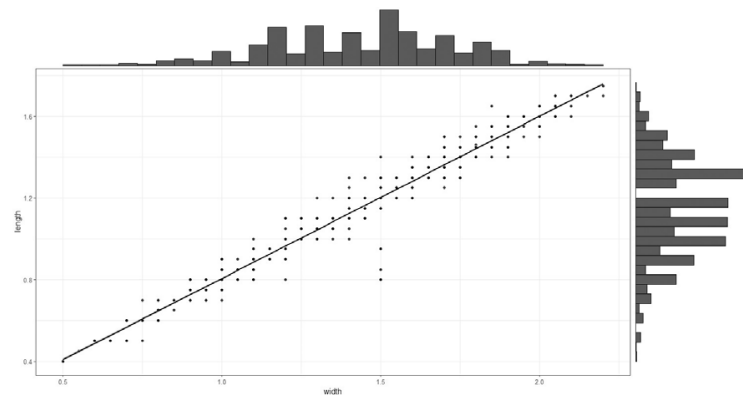

Fig. 5. Scatter plot with marginal histograms showing the correlation (and 95\% confidence interval of the regression line) between the carapace length and width.

characteristic cheliped vesicle, a sign of sexual maturity and readiness for mating (FROGLIA \& MANNING, 1978).

The analysis of frequency distribution of female brooding stage, as well as for the presence/absence of the cheliped vescicle in males, did not evidence differences in relation with CW or CL (Table 2). By contrast, not brooding individuals prevailed in each female size class $(\mathrm{n}=292)$, as well as the presence of cheliped vescicle in males $(\mathrm{n}=879)$.

The regression analysis between $\mathrm{CW}$ and CL highlighted a strong correlation between these two variables (Fig. 5). A strong interaction with sex variable was recorded $(\mathrm{p}$-value $=$ $5.41 \mathrm{e}-07 * * *)$, with the males appearing bigger than the females. The regression model, both for the male and female components, highlighted a strong correlation with the season and the time of the day considered, with the smallest indi-

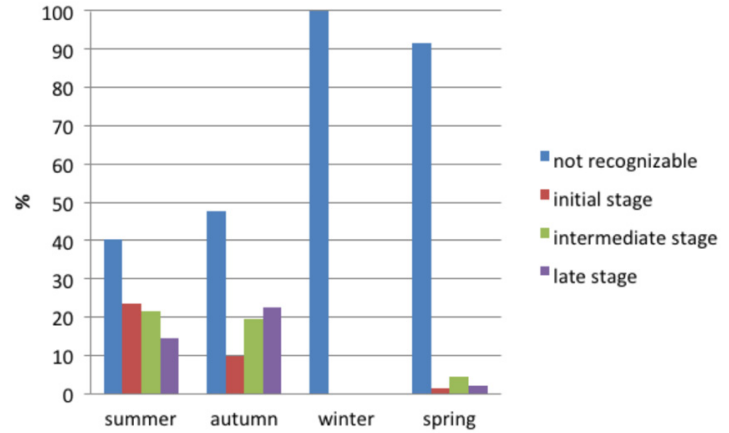

Fig. 6. Percentage of not ovigerous and ovigerous females in the four seasons. Three stages of gonad maturity are separately considered.

viduals recorded in autumn and during sunset (Table 3). Even if not statistically significant, the average female $\mathrm{CW}$ resulted similar for stations $\mathrm{A}$ and $\mathrm{B}$, while in $\mathrm{C}$ animals were larger. Males were found more frequently in summer and autumn in stations B and C.

As far as concerns the role of cheliped vesicles, preliminary in aquaria observations carried out on 60 random couples of juveniles vs. juveniles, juveniles vs. adults, and adults vs. adults (each counting 20 observations), revealed competitive behaviour only and always between specimens both exhibiting vesicles.

\section{DISCUSSION}

The present data, indicating eutrophic environments as preferred habitat of Brachynotus sexdentatus, agree with literature data reporting this species from harbour fouling (FROGLIA \& MANNING, 1978), Musculista senhousia beds (MUNARI \& MISTRI, 2007), Pholas dactylus beds (MICU, 2007) and manila clam beds (LUDOVISI et al., 2013), but population density in Lake Ganzirri is notably lower than how reported e.g. for the Po River estuary (MISTRI \& ROSSI, 1999).

Such a tolerant (STABILI et al., 2013) and opportunistic species, takes advantage of environmental changes, whether increased eutrophication (SHADRIN et al., 2016) or ecological restoration (OUNIFI-BEN AMOR et al., 2017); by contrast, a rapid population decline following the settlement of the north Atlantic $R$. harrisii in Black Sea suggests that the native B. sexdentatus might suffer competition with invasive 
Table 3. Results of general linearized models performed on crustacea CW, CL, and sampling station, season and time of

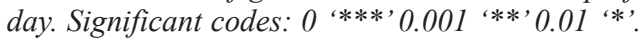

\begin{tabular}{|c|c|c|c|}
\hline \multicolumn{4}{|l|}{ Model } \\
\hline \multicolumn{4}{|l|}{$\mathbf{C W}=\mathbf{C L}$} \\
\hline $\begin{array}{l}\text { Intercept } \\
\text { CL }\end{array}$ & $\begin{array}{l}\text { Estimate } \\
0.038348 \\
1.212925\end{array}$ & $\begin{array}{l}\text { Standard Error } \\
0.007212 \\
0.006150\end{array}$ & $\begin{array}{l}\text { P value } \\
1.22 \mathrm{e}-07^{* * * *} \\
<2 \mathrm{e}-16^{* * * *}\end{array}$ \\
\hline \multicolumn{4}{|c|}{ CW $($ males $)=$ station + season + time of the day } \\
\hline $\begin{array}{l}\text { Intercept } \\
\text { station B } \\
\text { station C } \\
\text { season spring } \\
\text { season summer } \\
\text { season winter } \\
\text { time of the day sunrise } \\
\text { time of the day sunset }\end{array}$ & $\begin{array}{l}\text { Estimate } \\
1.33145 \\
0.01055 \\
0.01119 \\
0.29779 \\
0.24678 \\
0.27958 \\
0.01255 \\
0.05539\end{array}$ & $\begin{array}{l}\text { Standard Error } \\
0.02437 \\
0.02333 \\
0.02410 \\
0.02492 \\
0.01930 \\
0.04165 \\
0.02210 \\
0.02108\end{array}$ & $\begin{array}{l}\text { P value } \\
<2 \mathrm{e}-16 * * * \\
0.65135 \\
0.64251 \\
<\mathbf{2 e - 1 6 * * *} \\
<\mathbf{2 e - 1 6 * * *} \\
\mathbf{3 . 2 6 e - 1 1 * * *} \\
0.57041 \\
\mathbf{0 . 0 0 8 7 3 * *}\end{array}$ \\
\hline \multicolumn{4}{|c|}{ CW $($ females $)=$ station + season + time of the day } \\
\hline $\begin{array}{l}\text { Intercept } \\
\text { station B } \\
\text { station C } \\
\text { season spring } \\
\text { season summer } \\
\text { season winter } \\
\text { time of the day sunrise } \\
\text { time of the day sunset }\end{array}$ & $\begin{array}{l}\text { Estimate } \\
1.233429 \\
0.024844 \\
0.052098 \\
0.300118 \\
0.287593 \\
0.312050 \\
0.005918 \\
0.049732\end{array}$ & $\begin{array}{l}\text { Standard Error } \\
0.027147 \\
0.024807 \\
0.028172 \\
0.026301 \\
0.025475 \\
0.041786 \\
0.026874 \\
0.024057\end{array}$ & 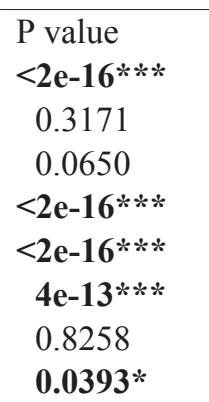 \\
\hline
\end{tabular}

crabs sharing the same habitat (ZALOTA et al., 2016; 2017).

Our preliminary data, indicating hard substrates as selective habitat for juveniles, with respect to soft bottoms that are preferred by adults, indicates different habitat preferences (CHU et al., 2013) and related resources partitioning; moreover, whilst adults tend to be confined in the inner areas, juveniles prevail outer, in agreement with the zoeal development of $B$. sexdentatus, that occurs in open sea, reinvading the estuarine inlet at megalopae stage using tidal-stream transport (GONZÁLES-GORDILLO et al., 2003). Such strategy, known for other estuarine decapods (ABELLÓ et al., 1997), favours dispersal, reduces predation and exposes early stages to a lower environmental variability (OLAGUERFELIÚ et al., 2010). The differential distribution of adults, characteristic of male biased intertidal crabs (UNNO \& SEMENIUK, 2011), in B. sexdentatus involves size-related differences between sex, station, season, and female reproductive phase. Similarly to other brackish dominant decapods (DAOULATLI et al., 2014), in fact, seasonal changes and marked, sex related, spatial dynamics have been proved. In particular, female distribution was mainly influenced by season and brooding status, rather than time of day. By contrast, the high mobility of the numerically predominant males, which contrasts with a predominance of females reported for other native (CANNICCI et al., 1999) and introduced (DEUDERO et al., 2005) Mediterranean Grapsoidae, may represent a strategy to mitigate a high sperm competition intensity (HAZLETT et al., 2005; WANG et al., 2008).

Cheliped vesicles, in this respect, according to preliminary observations, might play a role in 
agonistic and courtship behaviours, since strategy which may involve a lower energetic effort rather than increased body size or heterochely.

In our opinion, the constant presence of vesicles throughout the year is a further indication of high male reproductive competition, linked to a low percentage of mature females, in spite of their prolonged presence in accordance with the highly male-biased sex ratio, known for grapsid with restricted female receptivity (BROCKERHOFF \& MCLAY, 2005).

The slightly larger size of mature males with respect to females, frequently reported in small sized species, also agrees with the one observed in the congeneric B. foresti Zariquiey Álvarez, 1968 (SANZ-BRAU \& MESQUITA-JOANES, 2018).

Present indications of a prolonged spawning, supported by the unimodal size frequency distribution, in agreement with GONZÁLES-GORDILLO \& RODRIGUEZ (2003) involve an almost continuous recruitment, coupled with slow development and constant mortality rates (CHU et al. 2013). Life span is probably annual. Such highly dynamic life cycle agrees with that observed in other Varunidae whose reproduction is not rigidly programmed (ITUARTE et al., 2004).

\section{CONCLUSIONS}

B. sexdentatus, known for a wide range of transitional waters, inside the Lake Ganzirri is a characterizing species, whose functional role of epifaunal motile herbivorous and as part of the fish assemblage diet, connects benthic primary production with secondary consumers. Space-time dynamics, on seasonal scale, suggests different sex strategies, that in females might favour surviving and gonad maturation, whilst in males might reduce sperm competition in a male biased population. In this respect, a peculiar structure as the male cheliped vesicles might play a prominent role, both ethological and physiological, which needs to be carefully investigated.

\section{ACKNOWLEDGEMENTS}

We warmly thank the "Provincia Regionale di Messina", official management body of the reserve which authorized sampling and field studies (permission n. 557/VIII DIR, 12.03.2014), also providing contextual hydrological parameters. In field facilities have been provided by the mussel farm FARAU s.r.l.

\section{REFERENCES}

ABELlÓ, P., J. VALLADARES \& A. CASTELlÓN. 1988. Analysis of the structure of decapod crustacean assemblages off the Catalan coast (North-West Mediterranean). Mar. Biol., 98: 39-49.

ABELlÓ, P., A. AAGAARD, C.G. WARMAN \& M.H DEPLEDGE. 1997. Spatial variability in the population structure of the shore crab Carcinus maenas (Crustacea: Brachyura) in shallow-water, weakly tidal fjord. Mar. Ecol. Prog. Ser., 147: 97-103.

ATKINSON, R.J.A., C. FROGLIA, E. ARNERI \& B ANTOLINI. 1998. Observations on the burrows and burrowing behavior of Brachynotus gemmellari and on the burrows of several other species occurring on Squilla grounds off Ancona, Central Adriatic. Sci. Mar., 62(12): 91-100.
AYDIN, M. \& E.G.T. BENGIL. 2020. Feeding Habit and Length-Weight Relationship, Sciaena umbra Linnaeus, 1758 from Southeastern Black Sea. ActAquaTr, 16(4): 479-486.

AYDIN, M. \& R.E. MAZLUM. 2020. Feeding ecology of black scorpion fish (Scorpaena porcus Linnaeus, 1758) in SE Black Sea region, (Ordu) Turkey. JMBA: 1-10. https://doi. org/10.1017/S002531542000020X

BALKIS, H., N. BALKIS \& S. ALTINSAÇLI. 2001. The crab species found on the coasts of Gökçeada (Imbroz) Island in the Aegean Sea. Hydrobiologia, 449: 99-103.

BENGIL, E.G.T. \& M. AYDIN. 2020. The length and weight relationships and feeding ecology of knout goby, Mesogobius batrachocephalus (Pallas, 1814) from Southern Black Sea. Ege JFAS, 37(4): 409-414. 
BOTTARI, A., C. BOTTARI, P. CARVENI, S. GIACOBBE \& N. SPANÒ. 2005. Genesis and geomorphologic and ecological evolution of the Ganzirri salt marsh (Messina, Italy). Quat. Int., 140-141: 150-158.

BROCKERHOFF, A.M. \& C.L. MCLAY. 2005. Comparative analysis of the mating strategies in grapsid crabs with special references to the intertidal crabs Cyclograpsus lavauxi and Helice crassa (Decapoda: Grapsidae) from New Zeland. J. Crustac. Biol., 25(3): 507520.

CANNICCI, S., J. PAULA \& M. VANNINI. 1999. Activity pattern and spatial strategy in Pachygrapsus marmoratus (Decapoda: Grapsidae) from Mediterranean and Atlantic shores. Mar. Biol., 133: 429-435.

CHU, K.H. 1999. Morphometric analysis and reproductive biology of the crab Charybdis affinis (decapoda, brachyura, portunidae) from the Zhujiang Estuary, China. Crustaceana, 72 (7): 647-658.

CHU, T.J., Q. SHENG, S.K. WANG, M.Y. HUANG \& J.H. WU. 2013. Population dynamics and secondary production of crabs in a Chinese salt marsh. Crustac. Int. J. Crustac. Res., 86: 278-300.

CILENTI, L., G. D'ERRICO, T. SCIROCCO, C. MANZO \& A. FABBROCINI. 2014. Spatial variability in the population structure of the Carcinus aestuarii in Varano lagoon. TWB, 8: 24-31.

COMPAIRE, J.C., R. CABRERA, C. GÓMEZ-CAMA \& M.C. SORIGUER. 2016. Trophic relationships, feeding habits and seasonal dietary changes in an intertidal rockpool fish assemblage in the Gulf of Cadiz (NE Atlantic). J. Mar. Syst., 158: 165-172.

COMPAIRE, J.C., P. CASADEMONT, R. CABRERA, C. GÓMEZ-CAMA \& M. SORIGUER. 2018. Feeding of Scorpaena porcus (Scorpaenidae) in intertidal rock pools in the Gulf of Cadiz (NE Atlantic). JMBA, 98(4): 845-853.

DAOUlatli, A., M. ANTIT, A. AZZOUNA \& J.E. GARCÍA RASO. 2014. Seasonal and diel changes in the structure of a crustacean decapod assemblage associated to a shallow Cymodocea nodosa meadow in northern Tunisia (Mediterranean Sea). An overview of Medi- terranean decapod taxocoenoses. Medit. Mar. Sci., 15(1): 59-71.

DEUDERO, S., A. FRAU, M. CERDA \& H. HAMPEL. 2005. Distribution and densities of the decapod crab Percnon gibbesi, an invasive Grapsidae, in western Mediterranean waters. Mar. Ecol. Prog. Ser., 285: 151-156.

D’UDEKEM D'ACOZ, C., 1999. Inventaire et distribution des crustacés décapodes de l'Atlantique nord- riental, de la Méditerranée et des eaux continentales adjacentes au nord de $25^{\circ} \mathrm{N}$. Collection 'Patrimoines Naturels' (Mus. natn. Hist. nat.), Paris, 40: 1-383.

FERRARIN, C., A. BERGAMASCO, G. UMGIESSER \& A. CUCCO. 2013. Hydrodynamics and spatial zonation of the Capo Peloro coastal system (Sicily) through 3-D numerical modelling. J. Mar. Syst., 117-118: 96-107.

FROGLIA, C. \& R.B. MANNING. 1978. Brachynotus gemmellari (Rizza, 1839), the third Mediterranean species of the genus (Crustacea, Decapoda, Brachyura). Proc. Biol. Soc. Wash., 91(3): 691-705.

GIACOBBE S. \& S. DE MATTEO. 2013. The potentially invasive opisthobranch Polycera hedgptethi Er. Marcus, 1964 (Gastropoda Nudibranchia), introduced in a Mediterranean coastal lagoon. Biodiversity Journal, 4(2): 359-364.

GONZÁLES-GORDILLO, J.I., A.M. ARIAS, A. RODRÍGUEZ \& P. DRAKE. 2003. Recruitment patterns of decapods crustacean megalope in a shallow inlet (SW Spain) related to life history strategies. Est. Coast. Shelf Sci., 56: 593-607.

GONZÁLES-GORDILLO, J.I. \& A. RODRÍGUEZ. 2003. Comparative seasonal and spatial distribution of decapod larvae assemblages in three coastal zones off the south-western Iberian Peninsula. Acta Oecol., 24: 219-233.

HAZLETT, B.A., C.E. BACH, G.A. THOMPSON \& C.L. MCLAY. 2005. Movement of male Heterozius rotundifrons (Crustacea: Decapoda: Brachyura) depends upon local sex ratio. N. Z. J. Mar. Freshw., 39: 157-163.

KHALIL, M.T., M.R. FISHAR, S.H. SHAKIR, A.S. AMER \& M.G. NASSIF. 2017. Impact of Drainage Water on Macrobenthos Structure of 
Lake Qaroun, El-Fayoum, Egypt. EJABF, 21(2): 17-32.

ITUARTE, R., E. SPIVAK \& T. LUPPI. 2004. Female reproductive cycle of the Southwestern Atlantic estuarine crab Chasmagnatus granulatus (Brachyura: Grapsoidea: Varunidae). Sci. Mar., 68: 127-137.

LEONARDI, M., F. AZZARO, M. AZZARO, G. CARUSO, M. MANCUSO, L.S. MONTICELLI, G. MAIMONE, B. LA FERLA., F. RAFFA \& R. ZACCONE. 2009. A multidisciplinary study of the Capo Peloro brackish area (Messina: Italy): characterization of trophic condition, microbial abundances and activities. PSZN I: Mar. Ecol., 30 (suppl. 1): 33-42.

LEWINSOHN, C. \& L.B. HOLTHUIS. 1964. New records of Decapod Crustacea from the Mediterranean coast of Israel and the Eastern Mediterranean. Zoologische Mededelingen, Leiden 40(8): 45-63

LUDOVISI, A., G. CASTALDELli \& E.A. FANO. 2013. Multi-scale spatio-temporal patchiness of macrozoobenthos in the Sacca di Goro lagoon (Po River Delta, Italy). TWB, 7(2): 233-244.

MANNING, R.B. \& Z. ŠTEVČIĆ, 1982. Decapod fauna of the Piran Gulf. Quaderni Lab. Tecnol. Pesca Ancona, 3 (2-5): 285-304.

MICU, D. 2007. Recent records of Pholas dactylus (Bivalvia: Myoida: Pholadidae) from the Romanian Black Sea, with considerations on its habitat and proposed IUCN Regional Status. Acta Zool. Bulg., 59(3): 267-273.

MISTRI, M. \& R. ROSSI. 1999. Structure and production of the benthic macroinvertebrate community in a shallow lagoon of the Po River Delta. Ital. J. Zool., 66: 361-368.

MUNARI, C. \& M. MISTRI. 2007. Structure and secondary production of the macrobenthic community in an aquatic transition environment of the Gulf of Olbia, Mediterranean Sea. Indian J. Mar. Sci., 36(3): 216-226.

NAYLOR, E., 1957. Introduction of a grapsoid crab Brachynotus sexdentatus (Risso) into British waters. Nature, 180: 616-617.

OLAGUER-FELIÚ, A.O., A.A.V. FLORES, H. QUEIROGA \& J.I. GONZALEZ-GORDILLO. 2010. Shelf and estuarine transport mechanisms affecting the supply of competent larvae in a suite of brachyuran crabs with different life histories. Mar. Ecol. Prog. Ser., 410: 125-141.

OUNIFI-BEN AMOR, K., M.M. BEN AMORM., M. RIFI \& J. BEN SOUISSI J. 2017. Diversity of crustacean species from Tunis Southern Lagoon (Central Mediterranean) after an ecological restoration. Cah. Biol. Mar., 58: 49-57.

PESSANI, D., R. BURRI \& I. SALTON I. 1998. A key for the identification of the known larval stages of the Mediterranean Brachyura. Invertebr. Reprod. Dev., 33: 191-199.

PESSANI, D., T. TIRELLI \& S. FLAGELLA. 2004. Key for the identification of Mediterranean brachyuran megalopae. Mediterr. Mar.Sci., 5(2): 53-64.

RODRÍGUEZ. G. \& H. SUAREZ. 2001. Anthropogenic dispersal of decapods crustaceans in aquatic environments. Interciencia, 26(7): 282-288.

SANZ-BRAU, A. \& F. MESQUITA-JOANES. 2019. Relative growth in the Mediterranean endemic shore crab Brachynotus foresti Zariquiey Álvarez, 1968 (Decapoda: Brachyura: Varunidae). J. Crustac. Biol., 39(4): 349-356

SHADRIN, N.V., G.M. EL-SHABRAWY, E.V. ANUFRIIEVA, M.E. GOHER \& E. RAGAB. 2016. Longterm changes of physicochemical parameters and benthos in Lake Qarun (Egypt): Can we make a correct forecast of ecosystem future? KMAE, 417(18):1-11. DOI: 10.1051/ $\mathrm{kmae} / 2016005$

SCHUBART, C.D., J. A. CUESTA \& A. RODRÍGUEZ. 2001. Molecular phylogeny of the crab genus Brachynotus (Brachyura: Varunidae) based on the 16S rRNA gene. Hydrobiologia, 449: $41-46$.

STABILI, L., A. TERLIZZI \& R.A. CAVALLO. 2013. Sewage-exposed marine invertebrates: survival rates and microbiological accumulation. Environ. Sci. Pollut., 20: 1606-1616.

UNNO, J. \& V. SEMENIUK. 2011. Populiton dynamics of the Western Australian soldier crab Mictyris occidentalis Unno, 2008 (Brachyura, Mictyridae) in the Dampier Archipelago - 30 years of observations. Crustac. Int. J. Crustac. Res., 84(8): 905-937.

VELASCO, E.M., M.C. GÓMEZ-CAMA, J.A HERNANDO \& M.C SORIGUER. 2010. Trophic relation- 
ships in an intertidal rockpool fish assemblage in the gulf of Cádiz (NE Atlantic). J. Mare Syst., 80: 248-252.

WANG, Q., L. YANG \& D. HEDDERLEY. 2008. Function of prolonged copulation in Nysius huttoni White (Heteroptera: Lygaeidae) under male-biased sex ratio and high population density. J. Insect Behav., 21: 89-99.

ZALOTA, A. K., U. V. SIMAKOVA, G. A. KOLYUCHKINA, S. E. ANOSOV \& V. A. SPIRIDONOV. 2016. The enigma of small crab Brachynotus sexdentatus Risso, 1827 (Crustacea Brachyura Varunidae) in the Black Sea - Azov Basin. $51^{\text {st }}$ EMBS, Rhodes, 26-30 September 2016: 63

ZALOTA, A. K., A. V. TIUNOV, S. V. BIRIUKOVA \& V.
A. SPIRIDONOV. 2017. The Trophic Position of the Alien Crab Rhithropanopeus harrisii (Crustacea Decapoda Panopeidae) in the Taman Bay, Sea of Azov Community. Oceanology, 57(2): 289-297.

ZUPO, V. \& T. VIEL. 2021. Ocean Acidification alters the composition of decapods crustacean communities associated to Posidonia oceanica beds. BORNH, 1(1): 19-27. DOI: https://doi.org/10.6092/2724-4393/7585

ZUUR, A.F., E.N. IENO \& C.S. ELPHICK. 2010. A protocol for data exploration to avoid common statistical problems. Methods Ecol. Evol., 1: 3-14.

Received: 8 March 2021

Accepted: 23 October 2021 


\title{
Dnevna i sezonska dinamika populacije Brachynotus sexdentatus (Risso, 1827) (Varunidae: Brachyura: Decapoda) u umjerenom priobalnom jezeru
}

\author{
Salvatore GIACOBBE*, Paolo De PASQUALE i Erika M.D. PORPORATO \\ *Kontakt, e-pošta: sgiacobbe@unime.it
}

\begin{abstract}
SAŽETAK
Grapsoidni rak iz porodice Varunidae, Brachynotus sexdentatus (Risso, 1827) mali je mediteranski rak čija je ekologija slabo poznata unatoč tome što je često citiran u znanstvenoj literaturi. Visoke gustoće koje se povremeno bilježe u staništima ušća ukazuju da bi ova oportunistička vrsta mogla igrati funkcionalnu ulogu $\mathrm{u}$ povezivanju primarne proizvodnje $\mathrm{u}$ bentosu s potrošnjom na višim trofičkim razinama.

U bočatom jezeru Ganzirri (sjeveroistočna Sicilija) živi populacija ovog raka, čija različita distribucija juvenilnih i odraslih jedinki, na tvrdim i mekim podlogama, uključuje različite preferencije staništa i posljedičnu podjelu resursa.

Istraživanje dnevne i sezonske dinamike odraslih primjeraka na mekom dnu pokazalo je da je populacija pristrasna muškoj, s razlikama u veličini između spola, stanice, sezone i reproduktivne faze ženki. Naši podaci, koji upućuju na godišnji životni vijek, produljeno mriješćenje i povezano kontinuirano regrutiranje, u skladu su s intrinzičnom nepredvidljivošću koloniziranog bočatog okoliša.

Konačno, preliminarna opažanja u akvarijima na karakterističnim muškim vezikulama kliješta, pokazala su da bi oni mogli biti uključeni u agonističko i udvaračko ponašanje.
\end{abstract}

Ključne riječi: litoralni rakovi - Brachyura; omjer spolova; boćate lagune; dinamika zaštićenih okoliša; Sredozemlje 